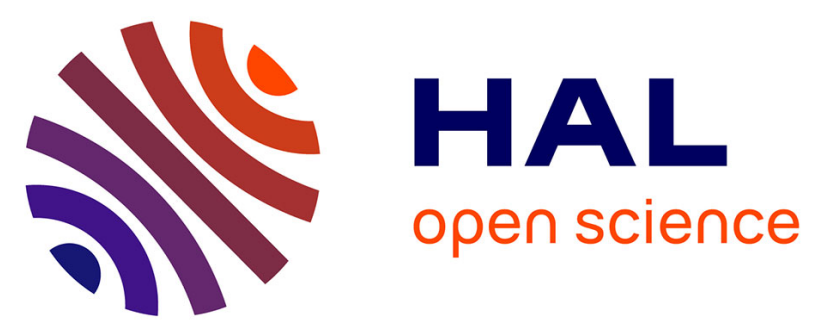

\title{
Fault detection and identification using simple and non-intrusive on-line monitoring techniques for PEM fuel cell
}

\author{
Emmanuel Frappé, Alexandre de Bernardinis, Olivier Bethoux, Claude \\ Marchand, Gérard Coquery
}

\section{To cite this version:}

Emmanuel Frappé, Alexandre de Bernardinis, Olivier Bethoux, Claude Marchand, Gérard Coquery. Fault detection and identification using simple and non-intrusive on-line monitoring techniques for PEM fuel cell. 2010 IEEE International Symposium on Industrial Electronics (ISIE 2010), Jul 2010, Bari, Italy. pp.2029-2034, 10.1109/isie.2010.5637474 . hal-02054622

\section{HAL Id: hal-02054622 https://hal.science/hal-02054622}

Submitted on 8 Mar 2019

HAL is a multi-disciplinary open access archive for the deposit and dissemination of scientific research documents, whether they are published or not. The documents may come from teaching and research institutions in France or abroad, or from public or private research centers.
L'archive ouverte pluridisciplinaire HAL, est destinée au dépôt et à la diffusion de documents scientifiques de niveau recherche, publiés ou non, émanant des établissements d'enseignement et de recherche français ou étrangers, des laboratoires publics ou privés. 


\section{Accepted Manuscript}

Fault detection and identification using simple and non-intrusive on-line monitoring techniques for PEM fuel cell

E. Frappé, A. De Bernardinis, O. Bethoux, C. Marchand and G. Coquery

DOI:

doi: $10.1109 /$ ISIE.2010.5637474

Reference: $\quad$ IEEE-ISIE, Bari 2010

Publisher: $\quad$ IEEE

To appear in:

IEEE Conferences

Conference date: $\quad$ 4-7 July 2010

Date of Publication: 15 November 2010 (available on line)

Please cite this article as:

E. Frappé, A. De Bernardinis, O. Bethoux, C. Marchand and G. Coquery, "Fault detection and identification using simple and non-intrusive on-line monitoring techniques for PEM fuel cell", 2010 IEEE International Symposium on Industrial Electronics, Bari, 2010, pp. 2029-2034, doi: 10.1109/ISIE.2010.5637474

URL: http://ieeexplore.ieee.org/stamp/stamp.jsp?tp=\&arnumber=5637474\&isnumber=5635477

Document Version: $\quad$ Early version, also known as pre-print

This is a PDF file of an unedited manuscript that has been accepted for publication. As a service to our customers we are providing this early version of the manuscript. The manuscript will undergo copyediting, typesetting, and review of the resulting proof before it is published in its final form. Please note that during the production process errors may be discovered which could affect the content, and all legal disclaimers that apply to the journal pertain. 


\title{
Fault Detection and Identification using Simple and Non-Intrusive On-line Monitoring Techniques for PEM Fuel Cell
}

\author{
Emmanuel Frappé ${ }^{1}$, Alexandre De Bernardinis ${ }^{1}$, Olivier Bethoux ${ }^{2}$, Member IEEE, \\ Claude Marchand ${ }^{2}$, Member IEEE, and Gérard Coquery ${ }^{1}$ \\ ${ }^{1}$ INRETS LTN/SPEE Labs, 25, allée des Marronniers - Satory, FR- 78000 Versailles \\ emmanuel.frappe@inrets.fr, alexandre.de-bernardinis@inrets.fr \\ 2 LGEP CNRS UMR 8507/SPEE Labs, 11, rue Joliot Curie, Plateau du Moulon, FR- 91192 Gif sur Yvette \\ olivier.bethoux@lgep.supelec.fr
}

\begin{abstract}
This paper scope is centered in the PEM fuel cell stack health diagnosis. For this purpose, authors present fault detection and identification methods using simple and non-intrusive on-line monitoring techniques. The approach is gradual based on detection and identification methods applied to a single cell up to multi-cells stacks used for power applications like transportation. A very low number of sensors are needed for the monitoring and the technique can be implemented on-line. Numerical simulation results illustrate the advantages of the different techniques.
\end{abstract}

Keywords — PEMFC, Fault detection, Cell on-line monitoring, Non-intrusive techniques.

\section{INTRODUCTION}

Environmental issues have increased the demand for less polluting energy generation technologies. Recent development of Proton Exchange Membrane Fuel Cell (PEMFC) makes them almost commercially available for stationary and transport application and offers significant advantages like high efficiency, low emissions, noiseless and makes them attractive. For transport application, the need of a high power and reliable generator $(>100 \mathrm{~kW})$ suggests the use of multi-stack fuel cell generator which allows high power combined with multiple single "low power" stacks and allows system redundancy [1].

To obtain its best performance, PEM fuel cell stack has to operate at a very precise but difficult to maintain operating point. Due to complex phenomena occurring in the heart of the PEM fuel cell, the dynamic behavior is not well understood resulting in the appearance of faults which has to be avoided. Consequently, the reliability and operability of the PEM Fuel Cell are affected and should be strengthened. Most common faults are cell flooding, membrane drying and poisoning of the catalysts areas. PEM fuel cells use a solid polymer electrolyte membrane (based on Nafion ${ }^{\circledR}$ ). This membrane, in order to be a performing ionic conductor, needs to be permanently wet. Flooding, due to an excess of water in the cells inhibits gas transport to the reaction sites and reduces the surface area of the catalysts, resulting in significant and sometimes catastrophic decrease of the cell performance [2]. On the contrary, a drying situation results in an increase of the membrane resistivity [3-5]. Poisoning is owing to the quality of gaseous hydrogen $\left(\mathrm{H}_{2}\right)$ or air. If contaminants are present in the gas then they cause performance degradation of the fuel cell. For example, carbon monoxide (CO) binds strongly to platinum catalyst and reduces the active surface available for $\mathrm{H}_{2}$ adsorption. $\mathrm{CO}$ adsorption is a reversible phenomenon but most of the others contaminants are irreversibly adsorbed on the catalyst and block the reaction sites or penetrate the polymer membrane and reduce the proton conduction activity [6]. Other types of faults may appear, due to the balance of plants (BoP) components (auxiliaries of the fuel cell system) and can impact the operating conditions of the fuel cell stack.

In order to have a continuity of service, particularly for vehicle applications, it is crucial to detect an early fault. Sometimes, the operating conditions, dynamic load variations, but also possible defective auxiliaries can induce a fault in the stack. The best and easiest failure indicator is the cell voltage; indeed a fault when appears in a fuel cell will almost all the time cause a voltage drop. Thus it is quite easy to detect a fault using a voltage monitoring but hard to precisely identify its signature. Moreover it is important to proceed to the fault detection and identification on-line when the fuel cell is working. Such indicators on the state-of-health of the PEM fuel cell can be returned in real time to the supervisor [7].

Other techniques already exist for fault detection and identification like the online humidification diagnosis through the DC- 
Accepted article for publication in 2010 IEEE International Symposium on Industrial Electronics, ISIE 2010, Jul 2010, Bari, Italy. - Citation information: doi: 10.1109/ISIE.2010.5637474

Available online 15 November 2010

DC power converter by calculating the internal resistance from high frequency current and voltage ripples on the fuel cell [8] or diagnosis methodologies which can be implemented using the power electronic converter and its PWM control strategy [9]. Electrochemical techniques like electrochemical impedance spectroscopy (EIS) analysis and cyclic voltammetry (CV) [10] can be also used to study the behavior of the PEM fuel cell to different external operating conditions and diagnostic possible malfunctions. For example the $\mathrm{CV}$ method can detect faults of $\mathrm{H}_{2}$ desorption or adsorption by sweeping the fuel cell potential back and forth between two set voltage limits while the current is recorded. All these techniques, cited above, have been rather tested on low power stacks in laboratory environment. It should be noted that certain techniques involve expensive and sometimes voluminous devices to perform the identification, and for EIS in particular the stabilization around a working point is necessary and doesn't exist in real operation.

The paper presents a fault detection and identification involving simple and non-intrusive on-line monitoring techniques applied for PEM Fuel Cells. The approach is based on a graduated analysis: from the single cell to a multi-cell power stack. The paper is organized as follow: first a dynamic modeling for the fuel cell is presented which allows performing the simulations and studying the behavior of the PEM fuel cell when a fault occurs. Then, the paper focuses on the fault and identification for a single cell and extends gradually to the multi-cell stack. The approach for power stacks consists in monitoring localized cells (Groups of cells at stack inlet, center-stack or stack outlet) and the identification using the differential measurement method. In that case, a low number of voltage sensors and non-intrusive are used. Finally a synthesis and perspectives end the paper.

\section{FUEL CELL MODELLING}

Some work has already been reported in the literature, static and dynamic modeling based on empirical equations was given by [11-15].

The voltage drop across the fuel cell (FC) can be written as a function of the activation, ohmic and concentration polarizations given by:

$V_{\text {cell }}=E-\eta_{\text {act }}-\eta_{\text {ohm }}-\eta_{\text {conc }}$

With E the electromotive force given thanks to the Nernst equation:

$E=1.229-8.5 \times 10^{-4}\left(T_{f c}-298.15\right)+4.3085 \times 10^{-5} \times T_{f c}\left(\ln \left(P_{H 2}\right)+0.5 \ln \left(P_{O 2}\right)\right)$

$\mathrm{T}_{\mathrm{fc}}$ is the fuel cell stack temperature; $\mathrm{P}_{\mathrm{H} 2}$ and $\mathrm{P}_{\mathrm{O} 2}$ are the partial pressures of hydrogen and oxygen respectively.

The activation voltage losses represent the fact that some energy is needed to generate a reaction product. They are obtained by the Tafel equation:

$\eta_{\text {act }}=A \cdot \ln \left(\left(J+J_{n}\right) / J_{0}\right)$

with

$A=\left(R T_{f c}\right) /(2 \alpha F)$

$\mathrm{J}$ is the fuel cell current density, $\mathrm{J}_{\mathrm{n}}$ the leakage current density, $\mathrm{J}_{0}$ the exchange current density, $\mathrm{R}$ the perfect gas constant, $\alpha$ the charge transfer coefficient and $\mathrm{F}$ the Faraday's constant.

The ohmic voltage losses are due to the resistance for both electronic and ionic currents. They result in a slow and linear voltage drop with increasing current. The main parameter of this voltage drop is the membrane resistance $\mathrm{R}_{\mathrm{mem}}$ :

$\eta_{\text {ohm }}=R_{\text {mem }} . J$

The concentration voltage losses are due to internal inefficiencies at high levels of reactive consumption. They occur at very high current density and are obtained empirically:

$\eta_{\text {conc }}=m \cdot \exp (n \mathrm{~J})$

$\mathrm{m}$ and $\mathrm{n}$ are constant depending of the construction of the cell.

It is useful to formulate the real voltage of the cell when there is no current; this voltage is named the open circuit voltage.

$E_{\text {ocv }}$ is calculated by melting (2) with a part of (3): 
Accepted article for publication in 2010 IEEE International Symposium on Industrial Electronics, ISIE 2010, Jul 2010, Bari, Italy. - Citation information: doi: 10.1109/ISIE.2010.5637474

Available online 15 November 2010

$E_{o c v}=1.229-8.5 \times 10^{-4}\left(T_{f c}-298.15\right)+4.3085 \times 10^{-5} \times T_{f c}\left(\ln \left(P_{H 2}\right)+0.5 \ln \left(P_{O 2}\right)\right)+A \ln \left(J_{0}\right)$

$\eta_{\text {act2 }}=A \cdot \ln \left(J-J_{n}\right)$

More precisely the overall stack voltage becomes:

$V_{\text {cell }}=E_{o c v}-\eta_{\text {act } 2}-\eta_{\text {ohm }}-\eta_{\text {conc }}(9)$

In dynamical operating mode, the response of the fuel cell is affected by important phenomena during a short time: the charge double layer. This layer can store electrical charge and electric energy and acts like a capacitor. Consequently the voltage changes do not happen instantly. This double layer effect can be modeled by a capacitor [12, 16].

In the dynamical model, the capacitor is placed in parallel to the sources representing voltage losses ( $\eta_{\text {act2 }}$ and $\eta_{\text {conc }}$ ). That is the reason why we have to modify the model elements.

As a matter of fact, the fuel cell current density $\mathrm{J}$ is shared between the double layer capacitor and $\eta_{\text {act } 2 \text {, }} \eta_{\text {conc. Then the current }}$ in the voltage loss branch $\left(\mathrm{J}_{\mathrm{f}}\right)$ needs to be calculated. For that purpose, we proceed as follows:

$\eta_{\text {act2 }}$ is replaced with a current source $J_{\mathrm{f}}$ controlled by the voltage $\eta_{\text {act2}}$, which is calculated with the Kirchhoff's voltage law:

$\eta_{a c t 2}+\eta_{\text {conc }}=V_{c d l}$

$\eta_{a c t 2}=V_{c d l}-\eta_{c o n c}$

$\mathrm{J}_{\mathrm{f}}$ is calculated thanks to (8)

$J_{f}=\exp \left(\eta_{a c t 2} / A\right)-J_{n}$

$\eta_{\text {conc }}$ is a voltage source controlled by $\mathrm{J}_{\mathrm{f}}$. The ohmic loss is modeled by a resistor. The model representation with the double layer capacitor is given in Fig.1.

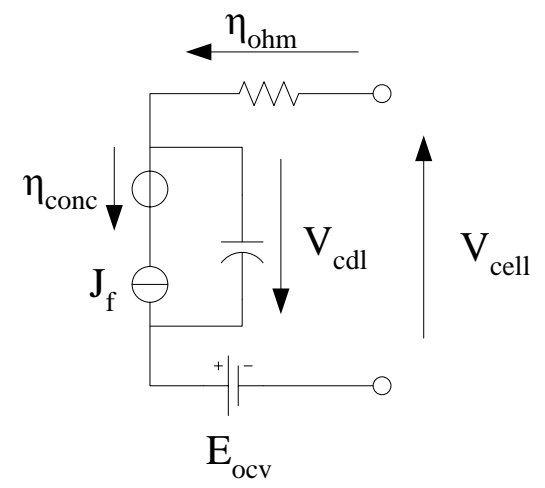

Fig. 1. Dynamic model: Representation of the double layer phenomena.

\section{FAULT DETECTION FOR A SINGLE CELL}

The best way to detect a fault is to monitor the cell voltage. Indeed when a fault occurs, the cell voltage drops. In this article we will focus on two kinds of fault: membrane drying and cell flooding. A drying, because of insufficient water concentration in the membrane will increase its resistance. In case of a flooding [11] explains that during flooding, the water forms a thin film blocking part of the active fuel cell area, this results in a lower apparent active area and so a higher current density.

\section{A. Polarization signature}

Fig. 2 shows a polarization curve of a cell during a normal working (A), a membrane drying (B) and a flooding (C). It shows, as already depicted in [17] that in the case of a drying or a flooding the voltage is almost the same from open circuit voltage down to the rated cell voltage. (The fuel cell should not be used under this voltage [18].). For the flooding curve (C), the active area was reduced to $80 \%$ by acting on the cell current as described in [11] and for drying membrane resistance was increase by 1.5 . 
Accepted article for publication in 2010 IEEE International Symposium on Industrial Electronics, ISIE 2010, Jul 2010, Bari, Italy. - Citation information: doi: 10.1109/ISIE.2010.5637474

Available online 15 November 2010

A first way to detect a fault is to define a threshold below which the cell is considered as faulty. But as shown by the polarization curve in Fig. 2 the cell voltage is not constant according to the current. We have to consider a dynamic threshold that will evolve with the current. Thanks to the identical fault signatures for drying and flooding, the threshold will be the same.

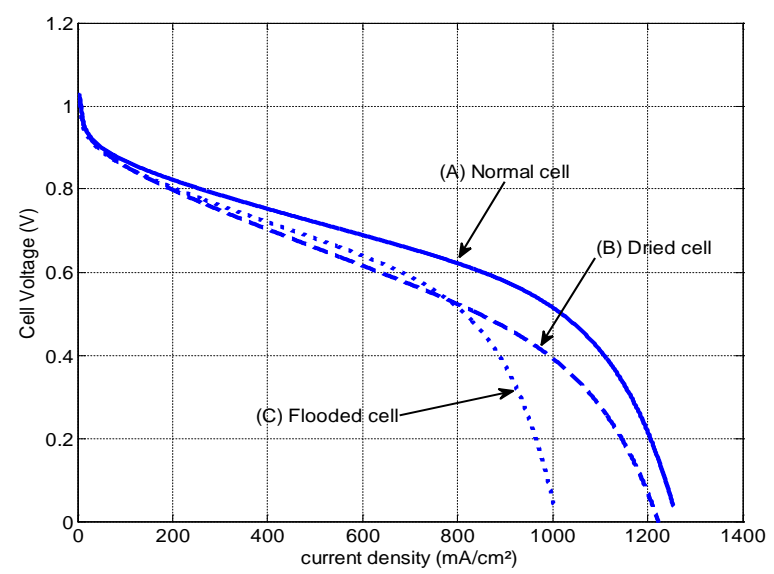

Fig. 2. Different polarization curves of a cell.

\section{B. Threshold for fault detection}

The threshold should be like a faulty cell polarization curve, so it is calculated with the voltage equation of the cell as follows:

Threshold $=E_{o c v}-A \cdot \ln \left(J_{T}-J_{n}\right)-R_{m e m} . J_{T}-m \cdot \exp \left(n J_{T}\right)$

With: $\quad J_{T}=$ measured current cell / $\left(S_{\text {cell }} * 0.9\right)$

In fact, the threshold will be a polarization curve with some degree of flooding; a new current density is calculated with a reduced active area (Here for example $90 \%$ of the real cell active area). When the cell voltage drops below the threshold, a fault is detected. Subsequently, the next step is to proceed to the identification.

\section{Fault identification}

Monitoring the cell voltage allows to detect a fuel cell fault, but it cannot identify it. That is the reason why we need to perform another action to identify it after onset of the faulty detection. The current interrupt method (CI) allows identifying the fuel cell parameters. The cell transient response is measured after a current interruption, or a high instantaneous drop of current. This current step has a high wide spectrum of frequencies which excite the fuel cell fundamental phenomena [19]. Fig. 3 shows three current interruptions: one for a healthy cell, one for a flooded cell and one for a drying cell. Flooding modifies the double layer effect while drying modifies only the membrane resistance. During the CI, the resistance of the membrane creates an abrupt step on the cell voltage and then the double layer effect generates a curved shape for the voltage response. [19] explains how to calculate FC parameters with a possible online technique.

Depending of the identified fault, actions can be performed on the fuel cell operating conditions in order to cancel the fault. In case of a flooding, gas flow or temperature should be increased. For a drying, temperature should be decreased or the inlet gas humidity should be increased. 
Accepted article for publication in 2010 IEEE International Symposium on Industrial Electronics, ISIE 2010, Jul 2010, Bari, Italy. - Citation information: doi: 10.1109/ISIE.2010.5637474

Available online 15 November 2010

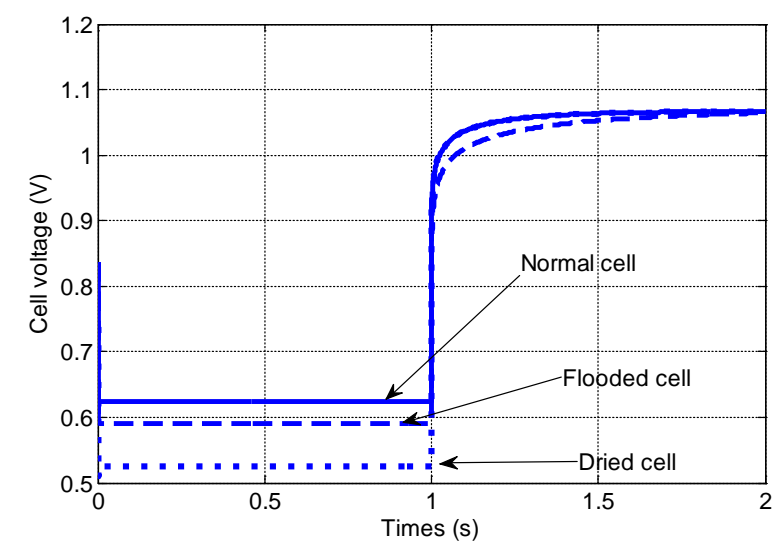

Fig. 3. Current interruption for a normal cell, a flooded cell and a dried cell.

\section{Sensitivity of the method}

1. Load cycle profile for transportation use

Because of the double layer effect and the slow fluidics dynamics, the polarization curve of the cell will present a hysteresis after a current cycling. Fig. 4(B) shows, in the J-V curve, the cell hysteresis with a current varying between 10 and $100 \mathrm{~A}$ and following a cycle similar to a transport cycle but on a very short time fig. 4(A). For the moment, our model does not take into account the fluidics which is a slow phenomenon because of the slow time constant of the auxiliary devices. As a result, the hysteresis bandwidth illustrated in our case is smaller than in a real cell. That is why we have to take it in account. Therefore, the threshold has to be set under this hysteresis so that transients are not detected instead of a fault.
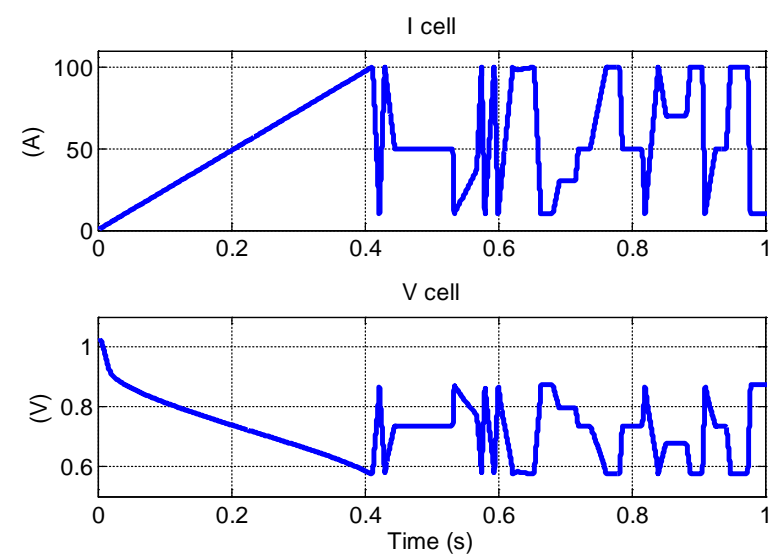

(A) Current and voltage during load cycle. 
Accepted article for publication in 2010 IEEE International Symposium on Industrial Electronics, ISIE 2010, Jul 2010, Bari, Italy. - Citation information: doi: 10.1109/ISIE.2010.5637474

Available online 15 November 2010

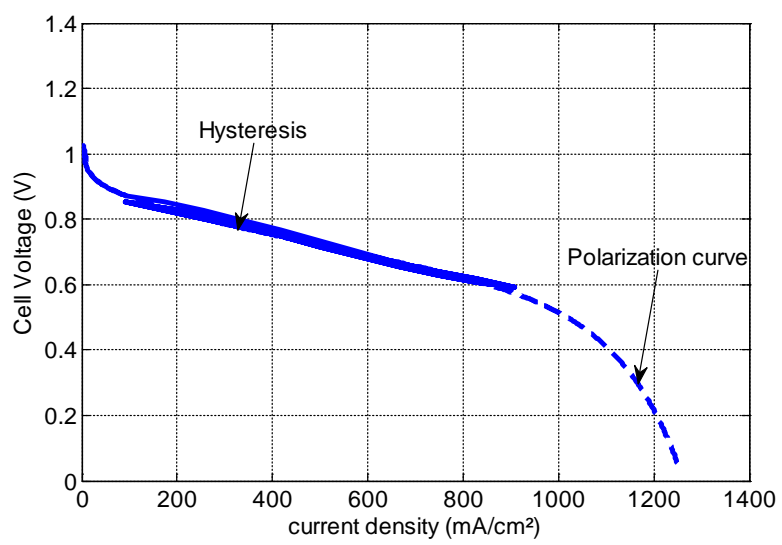

(B) Voltage hysteresis of a healthy cell.

Fig. 4.

2. Impact of external fluid conditioning

Operating conditions also have an important impact on the cell performance. Temperature or gas pressure variations modify the cell performance. Fig. 5 shows the cell voltage variation for different operating conditions.

Normal operating conditions are: temperature of the stack $65^{\circ} \mathrm{C}$, and pressure of gases $\left(\mathrm{H}_{2}\right.$ and air $) 2$ bars. A temperature decrease from 65 to $5^{\circ} \mathrm{C}$, increases the electromotive force $\mathrm{E}(2)$ and reduces the Tafel slope (3), but results in an exponentially lower exchange current density $\mathrm{J}_{0}$ [18]. Hence cell voltage decreases. A gas pressure drop from 2 to 1 bar results in a lower electromotive force (2) which reduces the cell voltage.

The last two figures highlight that operating conditions and load variation have an important impact on fuel cell voltage. This involves the fault detection $\mathrm{J}-\mathrm{V}$ curve to be low enough in order to detect only faults and not normal transient states of the cell voltage. It results in a not enough relevant detection.

In reality, the application involves a power stack which implies multiple cells in series to have a higher voltage output. The next following study is carried out for a full stack.

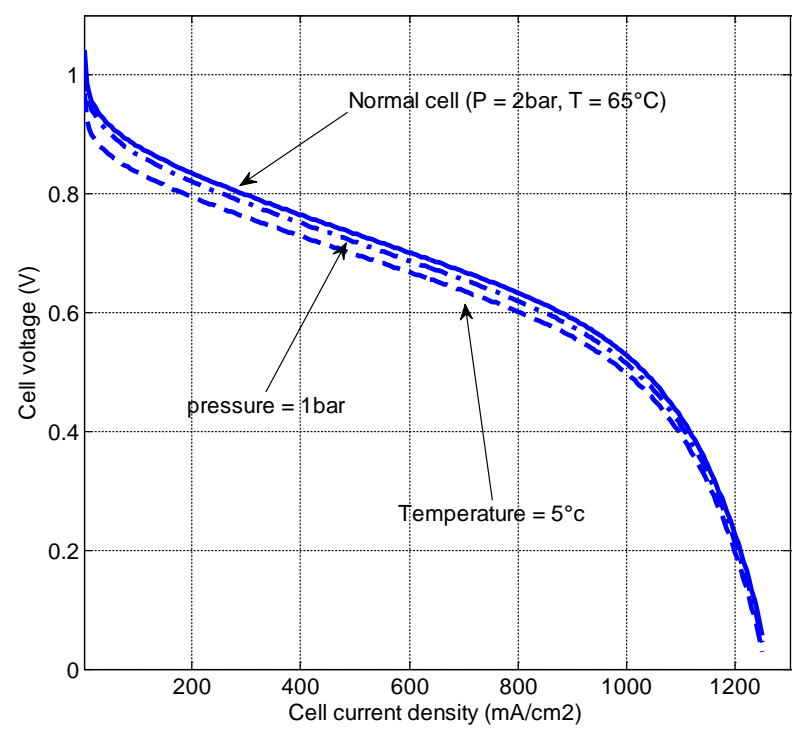

Fig. 5. Polarization curve with different operating conditions. 
Accepted article for publication in 2010 IEEE International Symposium on Industrial Electronics, ISIE 2010, Jul 2010, Bari, Italy. - Citation information: doi: 10.1109/ISIE.2010.5637474

Available online 15 November 2010

\section{FAULT DETECTION FOR A POWER STACK}

\section{A. Monitoring for a power stack}

Power FC stacks can easily be composed of hundreds of cells in series. In that case, it becomes difficult to monitor each cell. Besides [20] shows that flooding or drying never occurs in the entire stack but only affects some localized cells or group of cells.

Humidified air will quickly condense at the inlet of the stack. Besides water produced by the electrochemical reaction can easily accumulate at the outlet of the stack. Conversely the center of the stack is hotter than both ends; the presence of liquid water is lower. Hence a flooding may occur in the inlet and outlet of the stack while a drying may occur in the center of the stack. That is why, instead of monitoring all the cells, it could be judicious to monitor only a group of representative cells: a group of five cells in the inlet, five cells in the outlet for a possible flooding, and a group of five cells in the center of the stack for a possible drying.

\section{B. Detection and identification strategy using the differential method.}

Even if only three voltages are sensored (Fig. 6), the detection principle is based on the monitoring of a differential between the voltage in the center of the stack $\left(\mathrm{V}_{\text {center }}\right)$ and the inlet/outlet voltages (resp. $\left.\mathrm{V}_{\text {inlet, }} \mathrm{V}_{\text {outlet }}\right)$ as a new and accurate indicator of the state-of-health of the fuel stack. If all voltages are constants (there is no fault) or all voltages drop (there is a load variation): differential equal zero. If only $\mathrm{V}_{\text {center }}$ drops (there is a possible drying), the two differentials become positive. If the inlet or the outlet voltage drops (there is a possible flooding), one of two differentials becomes negative.

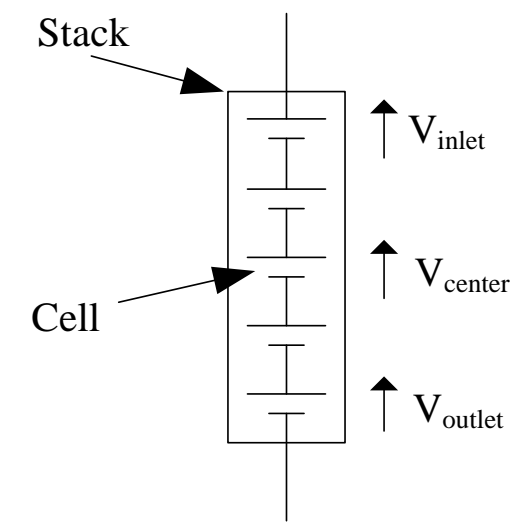

Fig. 6. Principle of monitored cells for a 5 cells FC stack.

Fig. 7 shows the detection method in the case of a flooding. Flooding occurs at 3 seconds in the outlet of the stack, water is slowly accumulated in the cells until the active area is reduced to $80 \%$, while voltage of outlet monitored voltage drops slowly. The entire stack voltage does not drop but by monitoring group of cells, it is possible to detect the early fault. One of the differential voltages ( $\mathrm{V}_{\text {outlet }}-\mathrm{V}_{\text {center }}$ ) is negative and is falling slowly as when the flooding increases.

Fig. 8 shows the case of a drying in the center cells. In this case, because the center cells are drying, their resistances increase up to a 1.5 factor, resulting in a voltage drop of center cells only. In that case the two differential voltages are positive and increase because $\mathrm{V}_{\text {center }}$ decreases. The stack voltage does not drop, but thanks to the differential voltages fault can be detected.

A very small voltage drop can be detected thanks to the differential voltage measure of a small group of cell. With this method, it is possible to detect a fault before the stack voltage drops in an obvious way.

Now it is important to control how the differential voltage evolves during transient operating.

Fig. 9 shows the case of a load variation of a healthy stack in order to validate the detection principle during transient. Here none of the cells is failing and so they all have the same voltage. During load variation, the entire stack is browsed by the same current, same operating conditions, and for this reason differential voltages do not evolve. 
Accepted article for publication in 2010 IEEE International Symposium on Industrial Electronics, ISIE 2010, Jul 2010, Bari, Italy. - Citation information: doi: 10.1109/ISIE.2010.5637474

Available online 15 November 2010

Thanks to the measurement a three small groups of cells, this fault detection method is very sensitive, it allows detecting early fuel cell failure, even before its impact on the stack voltage. With only three voltage measure, it requires a very low number of sensors and is a non intrusive technique for stack monitoring. It could be easily implanted in embedded applications.

The particularity of this method is the use of differential measure; it allows a good rejection of perturbation. For instance it is insensible to the polarization hysteresis or to the operational conditions of the stack. Drying and flooding can be indentified with this method depending of the position of the fail cells. Next a CI could be done in order to confirm the failure.
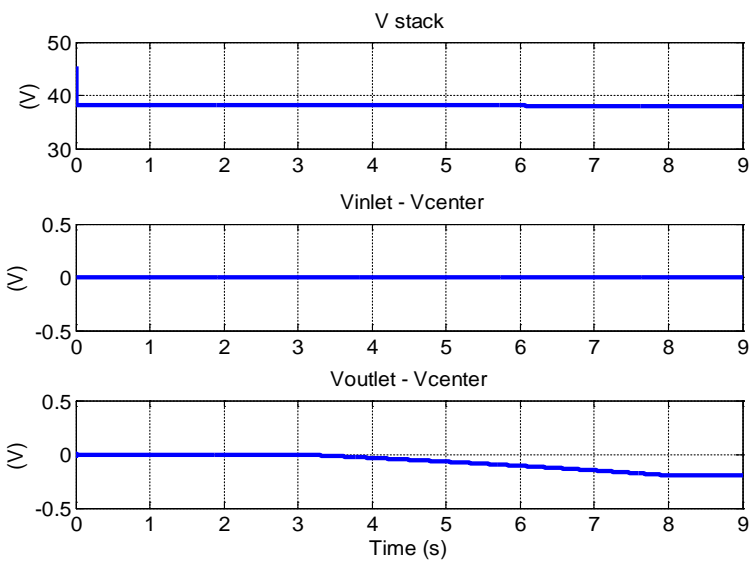

Fig. 7. Principle of monitored cells: flooding case.
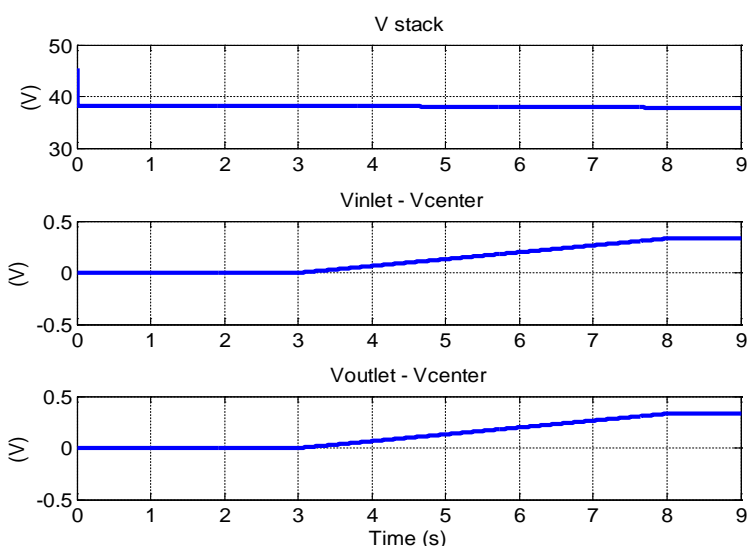

Fig. 8. Principle of monitored cells: drying case.
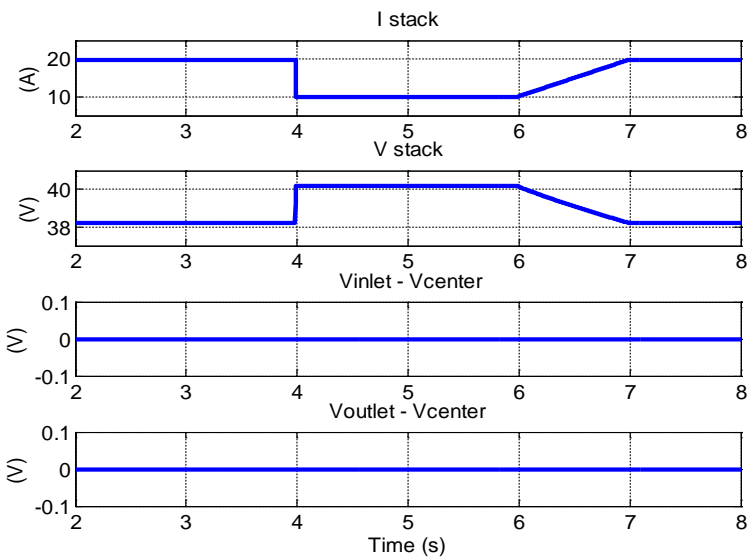

Fig. 9. Principle of monitored cells: healthy stack with current variation. 
Accepted article for publication in 2010 IEEE International Symposium on Industrial Electronics, ISIE 2010, Jul 2010, Bari, Italy. - Citation information: doi: 10.1109/ISIE.2010.5637474

Available online 15 November 2010

\section{CONCLUSION AND PERSPECTIVES}

Common failures in the PEMFC were discussed. With the objective of a continuity of service, it is important to detect and precisely identify them. Some identification techniques were presented (Electrochemical impedance spectroscopy EIS, current interrupt CI, and cyclic voltammetry CV methods) but some of them are not easy to implement. Only voltage monitoring is simple and non-intrusive.

Fault detection for one cell was presented, monitoring cell voltage drop gives good information about the state of health but its implementation in a power stack can be rather complex because of the high number of cells. Subsequently a new detection technique, using differential cell voltage of three groups of judiciously chosen cells was presented. It can differentiate between a flooding and a drying, is non intrusive and easy to implement. It gives relatively fast fault detection, provides simultaneously fault identification while requiring a low number of sensors.

Finally fuel cell output voltage is too low for high power applications; a power converter is needed to increase the output voltage. Consequently specific fault detection methods could be used with the power converter to detect, identify and act on the fuel cell to correct the failure. Power converter can perform a CI or an EIS to confirm the fail.

APPENDIX

\begin{tabular}{|l|l|l|}
\hline $\mathrm{T}_{\mathrm{fc}}$ & Fuel cell temperature & $343,15 \mathrm{~K}$ \\
\hline $\mathrm{P}_{\mathrm{H} 2}$ & Hydrogen pressure & $2 \mathrm{bar}$ \\
\hline $\mathrm{P}_{\mathrm{O} 2}$ & Oxygen pressure & $2 \mathrm{bar}$ \\
\hline $\mathrm{J}_{\mathrm{n}}$ & Leakage current density & $0.3 \mathrm{~A} / \mathrm{m} 2$ \\
\hline $\mathrm{J}_{0}$ & Exchange current density & $130 \times 10^{-4} \mathrm{~A} / \mathrm{m} 2$ \\
\hline$\alpha$ & Charge transfer coefficient & 2 \\
\hline $\mathrm{F}$ & Faraday's constant & $9.65 \times 10^{4} \mathrm{C} / \mathrm{mol}$ \\
\hline $\mathrm{R}$ & Perfect gas constant & $8.314472 \mathrm{~J} / \mathrm{mol} / \mathrm{K}$ \\
\hline $\mathrm{R}_{\mathrm{mem}}$ & Membrane resistance & $245 \times 10^{-6} \mathrm{k} \Omega . \mathrm{cm} 2$ \\
\hline $\mathrm{m}$ & Concentration coefficient & $2.11 \times 10^{-5}$ \\
\hline $\mathrm{n}$ & Concentration coefficient & $8 \times 10^{-3}$ \\
\hline $\mathrm{S}_{\mathrm{cell}}$ & Cell surface & $110 \mathrm{~cm} 2$ \\
\hline
\end{tabular}

\section{REFERENCES}

[1] B. Davat, S. Astier, T. Azib, O. Bethoux, D. Candusso, G. Coquery, A. De Bernardinis, F. Druart, B. François, M. Garcia Arregui, F. Harel, D. Hissel, JP. Martin, M-C. Péra, S. Pierfederici, S. Raël, D. Riu, S. Sailler, Y. Bultel, T. Creuzet, C. Turpin and T. Zhou, "Fuel cell-based hybrid systems," ELECTROMOTION, 1-3 July, 2009 , Lille, France.

[2] H. Li, Y. Tang, Z. Wang, Z. Shi, S. Wu, D. Song, J. Zhang, K. Fatih, J. Zhang, H. Wang, Z. Liu, R. Abouatallah, and A. Mazza, “A review of water flooding issues in the proton exchange membrane fuel cell,” Journal of Power Sources, Volume 178, pp. $103-117$.

[3] S. D. Knights, K. M. Colbow, J. St-Pierre, and D. P. Wilkinson, “Aging mechanisms and lifetime of PEFC and DMFC,” Journal of Power Sources, Volume 127, Issue 1-2, 2004, pp. 127-134. 
Accepted article for publication in 2010 IEEE International Symposium on Industrial Electronics, ISIE 2010, Jul 2010, Bari, Italy. - Citation information: doi: 10.1109/ISIE.2010.5637474

Available online 15 November 2010

[4] X. Xue, J. Tang, N. Sammes, and Y. Ding, “Model-based condition monitoring of PEM fuel cell using Hotelling T2 control limit,” Journal of Power Sources, Volume 162, Issue 1, 2006, pp. 388-399.

[5] N. Yousfi-Steiner, P. Moçotéguy, D. Candusso, D. Hissel, A. Hernandez, and A. Aslanides, "A review on PEM voltage degradation associated with water management: Impacts, influent factors and characterization,” Journal of Power Sources,Volume 183, Issue 1, 2008, pp. $260-274$.

[6] X. Cheng, Z. Shi, N. Glass, L. Zhang, J. Zhang, D. Song, Z.-S. Liu, H. Wang, and J. Shen, "A review of PEM hydrogen fuel cell contamination: Impacts, mechanisms, and mitigation,” Journal of Power Sources, Volume 165, Issue 2, 2007, pp. 739-756.

[7] O. Bethoux, M. Hilairet, and T. Azib, “A new on-line state-of-health monitoring technique dedicated to PEM fuel cell," IEEE IECON, 3-5 November, 2009, Porto, Portugal.

[8] M. Hinaje, I. Sadli, J.-P. Martin, P. Thounthong, S. Raël, B. Davat, “Online humidification diagnosis of a PEMFC using a static DC-DC converter," International Journal of Hydrogen Energy, Volume 34, Issue 6, March 2009, pp. 2718-2723.

[9] A. Narjiss, D. Depernet, D. Candusso, F. Gustin, and D. Hissel, "On-line diagnosis of a PEM Fuel Cell through the PWM converter," Proceedings of FDFC 2008, Nancy, France, 10-12 ${ }^{\text {th }}$ December 2008.

[10] S. Wasterlain, D. Candusso, D. Hissel, F. Harel, P. Bergman, P. Menard, M. Anwar, "Study of temperature, air dew point temperature and reactant flow effects on proton exchange membrane fuel cell performances using electrochemical spectroscopy and voltammetry techniques," Journal of Power Sources, Volume 195, Issue 4, 15 February 2010, pp. 984-993.

[11] A. J. del Real, A. Arce and C. Bordons, "Development and experimental validation of a PEM fuel cell dynamic model," Journal of Power Sources, Volume 173, Issue 1, 2007, pp. 310-324.

[12] V. Vishnyakov, "Proton exchange membrane fuel cells,” Vacuum, Volume 80, Issue 10, 2006, pp. 1053-1065.

[13] C. Wang, M. H. Nehrir, and S. R. Shaw, "Dynamic models and model validation for PEM fuel cells using electrical circuits," Energy Conversion, IEEE Transactions on, Volume 20, Issue 2, 2005, pp. 442- 451.

[14] D. Candusso, F. Harel, A. De Bernardinis, X. François, M. Péra, D. Hissel, P. Schott, G. Coquery, and J.-M. Kauffmann, "Characterisation and modelling of a 5 kW PEMFC for transportation applications," International Journal of Hydrogen Energy, Volume 31, Issue 8, 2006, pp. $1019-1030$.

[15] J. Larminie and A. Dicks, Fuel Cell Systems Explained, ed. (2003), John Wiley \& Sons.

[16] G. Fontes, C. Turpin, S. Astier, "A large signal dynamic circuit model of a H2/O2 PEM fuel cell: description, parameter identification and exploitation," Proceedings of FDFC 2008, Nancy, France, 10-12 $2^{\text {th }}$ December 2008.

[17] N. Fouquet, C. Doulet, C. Nouillant, G. Dauphin-Tanguy and B. Ould-Bouamama, "Model based PEM fuel cell state-of-health monitoring via ac impedance measurements," Journal of Power Sources, Volume 159, Issue 2, 2006, pp. 905-913.

[18] F. Barbir, "PEM fuel cells," Springer, 2005.

[19] M.A. Rubio, A. Urquia and S. Dormido, "Diagnosis of PEM fuel cells through current interruption,” Journal of Power Sources, Volume 171, Issue 2, 2007, pp. 670-677.

[20] A. Hernandez, R. Outbib, D. Hissel. "Diagnostic d'Une Pile à Combustible Pemfc. Une Approche Statistique,” Journal Européen des Systèmes Automatisés, Volume 42, Issue 10, 2008, pp. 1255-1277. 